\title{
Communities of practice for international students: an exploration of the role of Peer Assisted Study Sessions in supporting transition and learning in higher education
}

\section{Lucy Chilvers}

University of Brighton, UK

\section{Abstract}

There is growing interest in understanding how international students can best be enabled to adjust to, participate in and learn within Higher Education (HE). This paper explores literature and examines findings from exploratory interviews in a UK institution in order to investigate the contribution the Peer Assisted Study Sessions (PASS) scheme makes to this process.

Interviews with international students were analysed using Lave and Wenger's (1991) social-learning model, Communities of Practice (CoP), for exploring the role of PASS in supporting international students' transition and learning in HE. Using themes of community, practice and participation, findings illuminated the role of PASS in providing international students with an intermediary CoP, providing transition support into the CoP on their course and university life. PASS facilitated their social integration with students of other nationalities, developing relationships with peers and PASS leaders, contributing to an increased sense of belonging to a community. Through the mutual engagement of attendees and leaders, students developed shared language, values and practices relating to their discipline and studying in UK HE. Established PASS leaders shared first year experiences with 'newcomer' international students, supporting their transition into UK HE culture and enabling their legitimate peripheral participation to develop further. Participation in PASS fostered students' engagement with learning activities and independent study habits. Limitations to the study and suggestions for further research are discussed.

Keywords: communities of practice; international students; peer assisted learning; learning communities; participation; adjustment; transition. 


\section{Introduction}

In the context of the growing internationalisation of Higher Education (HE) (DeVita and Case, 2003), research evidences a variety of challenges and potential barriers to international students' transition into, and participation in, HE abroad (Krause, 2005). These can include homesickness, culture shock, loneliness and difficulties learning in English as a Second Language (ESL) (Jones and Fleischer, 2012a; Caruana and Spurling, 2007; Burns, 1991). These difficulties highlight the need for increased support for internationals, particularly in their first year (Anderson et al., 2009; Forland, 2006). This need for support is a common trend across UK HEls (Yorke and Longden, 2008) and is reflected in the retention data for the host institution of this research (Jones and Fleischer, 2012b). Between 2006/7 and 2010/11, international students' non-continuation rates increased each year at a faster rate compared to home students. There has been a steady improvement in international student retention since then, although it is still above the UK national benchmark.

The social learning concept Communities of Practice (CoP) (Lave and Wenger, 1991) describes a community of people, joined together by shared interests and a mutual participation in a particular practice. Research evidences the cultivating of student learning communities as an effective approach for supporting students in their academic, social and emotional adjustment to HE (Zhao and Kuh, 2004; Lenning and Ebbers, 1999). This positively impacts students' engagement, retention and overall satisfaction with their student experience (Zhao and Kuh, 2004; Tinto et al., 1994). Learning communities comprise of students who have regular contact with one another for the purpose of active, collaborative learning and socialising (Zhao and Kuh, 2004). Peer Assisted Study Sessions (PASS) is a peer learning scheme aimed at fostering a course-based learning community, evidenced in helping students to develop confidence, friendships, study skills and their understanding of course material (Fostier and Carey, 2007; Coe et al., 1999; Arendale, 1994).

Student PASS leaders from $2^{\text {nd }}$ and $3^{\text {rd }}$ year are trained and supervised to plan and facilitate regular, timetabled, small-group study sessions for $1^{\text {st }}$ year students. PASS is typically coordinated by centrally-based Academic Developers and school-based Supervisors. This study aims to explore the role of PASS as a CoP in supporting international students in their transition and learning in UK HE. 
Themes from both literature and CoP concept will be used to explore international students' experiences through some initial interviews at one UK HE Institution (HEI). Similarities and gaps identified between literature and student interviews will inform future research. For the purpose of this study international students are defined as any student who has moved to a different country to study (Biggs, 2003). However, it is acknowledged that the term international student represents a diverse, heterogeneous student population, so whilst this study represents individual students, it addresses common issues faced by a variety of international students evidenced in literature.

\section{Literature review Communities of Practice}

CoP originated from Lave and Wenger's (1991) Situated Learning theory, positing that learning is a social process occurring within a specific context. Vygotsky's (1978) Zone of Proximal Development also heavily informed CoP, highlighting the significant role of apprenticeship-type relationships between newcomers and more knowledgeable existing members who teach them a variety of values and practices (Lave and Wenger, 1991). This enables newcomers to develop from legitimate peripheral participation, to fuller participation and belonging to the community (Wenger, 1998).

Wenger (1998, p.5) argues that learning as social participation consists of four aspects which are 'deeply interconnected and mutually defining', including practice; meaning; community and identity. To address the research question and explore themes considered by the author most relevant to international students' experiences of PASS, in-depth focus shall be restricted to themes of community, practice and participation. Whilst these terms' meanings within CoP concept are complex, for the purpose of clarification they shall be defined. 'Community' refers to a special type of community whereby 'practice is the source of coherence' (Wenger, 1998, p.72). 'Practice' is people's mutual engagement in a joint enterprise consisting of shared repertoires (Wenger, 1998). Finally, 'participation' is defined as 'a process of taking part and also... the relations with others that reflect this process' (Wenger, 1998, p.53).

CoP concept has been used for exploring a number of dimensions of $\mathrm{HE}$ including adult education (Merriam and Caffarella, 1999); students' transition into HE (Tobell and O'Donnell, 2005); students' shifting identity formation in HE (O'Donnell and Tobell, 2007); 
and PASS as a CoP (Couchman, 2008). CoP concept can be useful for informing educational practitioners' understanding of the benefits of peer learning, thus enhancing the quality of learning and teaching.

It is argued that CoP are not cohesive homogenous units, but rather fluid and heterogeneous (Handley et al., 2006; Wenger, 1998). Literature identifies a number of CoP that international students could join on arrival at university, such as their course (O’Donnell and Tobell, 2007), wider subject discipline (Parker, 2002), friendship groups with co-nationals (Montgomery and McDowell, 2009), PASS (Couchman, 2008) and interest groups (Wenger, 1998). Building on Couchman's (2008) findings likening PASS to a CoP, this research explores the role of PASS in supporting international students in belonging to a PASS CoP, whilst also adjusting to additional CoP intrinsically linked to PASS on their course, discipline, and student life (Figure 1).

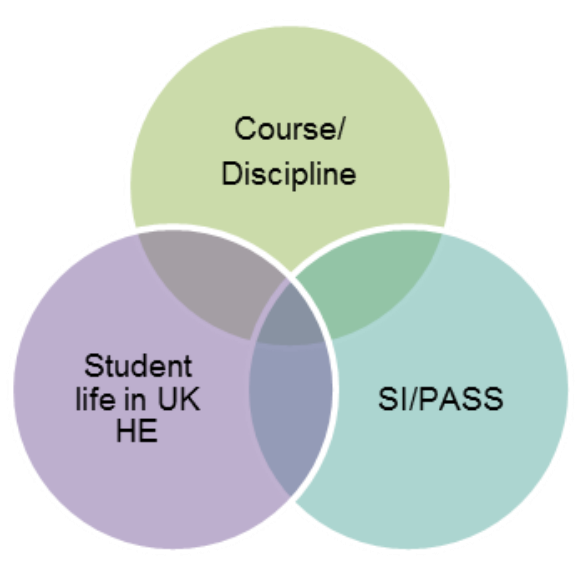

Figure 1. Multiple interconnecting CoP for international students in this research.

\section{Supporting international students' transition and learning}

Students' varying levels of skills and preparedness from their educational backgrounds creates a need for support in developing UK HE practices (Haggis, 2006), which can be particularly challenging for international students (Sovic, 2008; Caruana and Spurling, 2007).On arrival at university, international students have to adjust to 'multiple cultural frameworks: the host nation culture, the multicultural student cohort, the institutional culture of university and the disciplinary culture' (Schmidt and Miller, 2009, p.13).This process is described by Lave and Wenger (1991, p.95) as 'both absorbing and being absorbed in - the culture of practice'. Some students experience 'learning shock' (Gu, 2005; Krause, 2005) due to the host countries' different pedagogic methods, resulting in 
confusion and frustration (Gu, 2005), negatively affecting students' learning (Forland, 2006) and sense of belonging to a community (Lave and Wenger, 1991).

Developing stable relationships with course peers can positively impact students' social integration and belonging to their course community, consequently impacting retention (Thomas, 2012). However, for some international students studying, and speaking ESL, in front of peers can cause stress and anxiety, hindering social integration (Kingston and Forland, 2004; Burns, 1991). For other international students their preference for friendships with co-nationals for receiving comfort and support prevents them integrating with native students, hindering them improving their English, making cultural adaptations (Maundeni, 2001), and reducing the diversity of home students' learning experiences (DeVita, 2002).This highlights the potential benefits of PASS facilitating social integration. In light of these challenges, it is important to remember that international students may have previously been very successful members of a CoP in their previous educational institution, so experiencing these potential barriers can be a relatively new experience.

PASS offers students an opportunity to join and belong to a CoP on their course, involving the mutual engagement of attendees and leaders in a breadth of study practices. These practices range from collaborative and problem-based learning; reviewing course material; practicing study techniques, such as planning essays; and the social and universityspecific aspects of student life, such as using the library or living in student accommodation (Couchman, 2008). The supportive PASS environment facilitates students in practising shared languages, including a learning language regarding the practising of UK HE academic skills, the subject-specific discourse, and specifically for international students, the added complexity of learning in ESL, as summarised in Figure 2.

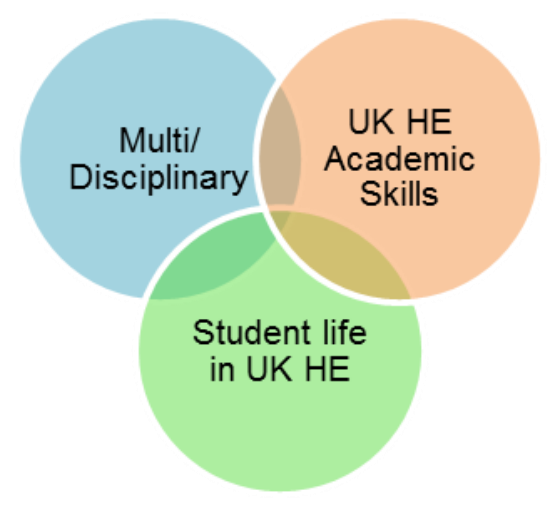

Figure 2. Multiple intersecting CoP within PASS. 
PASS leaders play a significant role in facilitating these PASS CoP using empathy, collaborative techniques, and an inclusive approach (List and Miller, 2013; Couchman, 2008). Whilst PASS leaders are more experienced members of the course's CoP, they are not 'experts' of their discipline. However, they do have an expertise of being a student on their course and studying at their university at a specific time - an expertise their lecturers do not have. PASS leaders are encouraged to support students by sharing their experiences of their course, university life and overcoming challenges (Couchman, 2008).

Whilst there is much research into international students' learning (Burns, 1991; Caruana and Spurling, 2007) and transition experiences (Anderson et al., 2009; Sovic, 2008), there appears to be little literature covering international students' participation in PASS. Schmidt and Miller (2009) investigated the impact PASS had on the transitions of international Masters students from Asian backgrounds studying at an Australian university. Students reported improved English language skills, developing friendships and receiving support in their adjustment to the Australian and university culture. Zaccagnini and Verenikina (2013) explored international students' perceptions of PASS, finding positive experiences of all surveyed. Students valued opportunities for interacting and asking questions in small groups with native students and PASS leaders. These studies suggest schemes dedicated to supporting students' development in a learning-community context, such as PASS, can help integrate international students into their course community. This research sought to contribute to this gap in literature by exploring international students' experiences of PASS as a CoP in greater depth. 


\section{Research methods}

\section{Methodology}

This research is informed by a social constructivist paradigm (Guba and Lincoln, 1994) in which knowledge is co-constructed through interaction between the active researcher and participant, and the researcher's interpretations of these interactions (Creswell, 2009). An interpretivist epistemological stance guided the study since the subjective lived experiences of individual students were being explored, and the researcher held an active role in shaping the data generation and analysis (Mason, 2002). Themes from CoP provided a conceptual lens to guide the data analysis.

\section{Interviews}

A small-scale qualitative approach was taken using semi-structured 45-minute interviews, exploring participants' individual perceptions and experiences (Ashley, 2012; Mason, 2002). In 2013-14 a random sample of six interview participants (Table 1) were recruited by e-mail and lecture announcements from second year international students in two departments with PASS. This small sample was intentional as this study aimed to explore themes from literature through exploratory interviews, and identify areas for more in-depth further research.

The interviews were designed in consideration of cultural differences in communication and language barriers (BERA, 2011; Kvale and Brinkman, 2009; Holstein and Gubrium, 2003). Levels of directness in conversation, modes of questioning and eye contact can all vary between cultures (Holstein and Gubrium, 2003). The furniture layout in the interview room intentionally avoided direct body language and eye contact, which can be perceived as uncomfortable and disrespectful (Holstein and Gubrium, 2003). The potential cultural differences were considered throughout the interviews, however, as all participants had previously spent time in UK institutions, there did not appear to be any major issues. At the start of the interviews, potential language barriers were addressed by inviting participants to draw a mind-map of their PASS experience in their first language, aiming to trigger their memories, and some participants made reference to these (Wheeldon and Faubert, 2009). 
Table 1. Participants' backgrounds.

\begin{tabular}{|c|c|c|c|c|c|}
\hline Participant & $\begin{array}{l}\text { Country } \\
\text { of origin }\end{array}$ & ESL? & $\begin{array}{l}\text { Time in UK } \\
\text { before } \\
\text { university? }\end{array}$ & Course & $\begin{array}{l}\text { PASS } \\
\text { attendance? }\end{array}$ \\
\hline P1 & Portugal & Yes & $\begin{array}{l}\text { Holidays and } \\
\text { studying } \\
\text { English }\end{array}$ & $\begin{array}{l}\text { Accountancy } \\
\text { and Finance } \\
(\mathrm{AF})\end{array}$ & $\begin{array}{l}\text { Most } \\
\text { sessions }\end{array}$ \\
\hline P2 & Germany & Yes & Holidays & AF & $\begin{array}{l}\text { First few, } \\
\text { stopped } \\
\text { going, joined } \\
\text { another } \\
\text { group, } \\
\text { attended last } \\
\text { few }\end{array}$ \\
\hline P3 & China & Yes & $\begin{array}{l}\text { Studying } \\
\text { English }\end{array}$ & $\mathrm{AF}$ & Most \\
\hline P4 & India & Yes & $\begin{array}{l}1 \text { year prior } \\
\text { to university, } \\
\text { studying } \\
\text { English }\end{array}$ & $\begin{array}{l}\text { Pharmaceutical } \\
\text { and Chemical } \\
\text { Sciences }\end{array}$ & All \\
\hline P5 & $\begin{array}{l}\text { South } \\
\text { Africa }\end{array}$ & $\begin{array}{l}\text { No - first. } \\
\text { School } \\
\text { education } \\
\text { in English }\end{array}$ & None & $\begin{array}{l}\text { Applied } \\
\text { Psychology and } \\
\text { Criminology }\end{array}$ & All \\
\hline P6 & Nigeria & Yes & None & Pharmacy & $\begin{array}{l}\text { Most; } \\
\text { changed } \\
\text { group in } \\
\text { semester } 2\end{array}$ \\
\hline
\end{tabular}

\section{Analysis}

The following research question informed the analysis: 'Drawing from CoP concept, how do exploring themes of community, practice and participation enable a greater understanding of the role of PASS in supporting international students' transition and 
learning in HE?'. Transcripts were thematically analysed using CoP concept themes of community, practice and participation; key quotes interpreted as representative of emerging findings were selected for discussion.

\section{Ethics}

Ethical considerations were particularly important due to the implications of my dual role as an academic and an insider researcher at the host institution. It was considered that participants might have felt concerned about the potential disclosure of their responses to the PASS Supervisor, who was one of their course tutors and also my colleague. In accordance with the British Educational Research Association (2011) and the host institution's guidance, the confidentiality and anonymity of student participants' identities and responses was guaranteed as much as possible, although limitations were made clear. A detailed information and consent form was developed to ensure participants understood the research process and reasons for it, how the data would be used, and their right to withdraw. Further explanation was provided during recruitment and at the start of the interviews (BERA, 2011).

\section{Findings}

Overall, findings suggest PASS provides international students with an intermediary CoP, supporting their transition and boundary crossing from their previous educational CoP into the CoP on their course, discipline and university student life. PASS facilitates their social integration into their course community, from peripheral to fuller participation as they acquire and build confidence in the cultural and academic practices. Findings shall be explained using the themes of community, practice and participation.

\section{Community}

The first theme of 'community' refers to people interacting and building relationships around specific shared activities and helping one another, thus creating a special type of community whereby 'practice is the source of coherence' (Wenger, 1998, p.72). The following further themes arose relating to community: 


\section{Peer relationships}

In support of Wenger's (1998) focus on interpersonal relationships being at the heart of COP, participants described PASS facilitating relationships with course peers:

My PASS group was nice because we could all talk... it was really easy way to meet lots of people... Everyone feels safe to contribute so you kind of get to know people quicker than just sitting next to a random person in a lecture. (P4)

Another participant observed how the formalities of the classroom can prevent students developing relationships:

Normally in lessons you wouldn't really talk to people that much because you're sitting there and the teacher doesn't really like you talking to your neighbours all the time. (P3)

PASS provided additional chances to socialise and nurture a greater sense of belonging to their course community.

\section{Learning from PASS leaders}

Supporting Zaccagnini and Verenikina's (2013) findings that the relationships between leaders and attendees is pivotal to building the PASS CoP, participants valued their relationships with their leaders:

It was mostly the idea of learning from your seniors, the ones who have already done first year... I liked the idea of learning from someone from their experience... [they] motivated me, they did well in exams, they worked hard, they got their placement. It gave me direction. (P4)

\section{Transition into community}

Reinforcing Schmidt and Miller's (2009) research evidencing PASS supporting postgraduate international students' transition and learning, participants described how PASS leaders shared their experience and advice, supporting their adjustment to life in the UK and university: 
I think for an international student you feel misplaced, like you've been dropped in... no real close relationship with anyone here, like floating. PASS made uni seem a bit more like home, you could attach yourself better, making the identity as a student. (P5)

\section{Social integration}

Participants' experiences agreed with literature that PASS facilitated their social integration (Zaccagnini and Verenikina, 2013; Schmidt and Miller, 2009). P1 and P4 observed how PASS helped international students to overcome the temptation to avoid socially integrating with students of other nationalities:

Usually international students love to stick together... it's actually quite hard to get to know people or find new friends...PASS helped you get along well with people that you don't know, working in groups or a team. (P1)

You go there [PASS] and you feel better and part of something else like a community... it made me gain confidence and socialise with different people. (P4)

P4 and P6 identified easier communication as their reason for being closer to other international students and co-nationals; for P6 PASS was the only time she socialised with home students:

They [other internationals] are in my situation so they understand me better than the national students. (P4)

The students I know from my home country are those I really know, the other students are just people in my class... PASS was the only time we would do anything more. (P6)

However, P5 had a proactive attitude towards integrating with home students:

I wanted to submerge myself in English culture and experience it. I wouldn't push anyone away if they were international... but I was really into making a group of English friends. (P5) 


\section{Practice}

The second theme of 'practice' refers to peoples' mutual engagement as practitioners in a joint enterprise consisting of shared repertoires and resources which are developed over time (Wenger, 1998). These themes emerged relating to practice:

\section{Shared language}

Participants referred to the variety of languages practiced in PASS, including a learning language regarding UK HE academic skills, subject-specific language, and the English language. Participants referred to their peers translating complex terminology and concepts using student-friendly language, enabling shared understanding:

Someone might put a complicated concept very basically that you might not have considered... leaders would simplify it. (P5)

Your teacher has got this level... you be scared to talk to them, but if you talk to the same age then you have common language. (P2)

P5 explained how her interdisciplinary PASS group enriched her understanding of her discipline beyond her course:

I noticed that their [joint-honours students] contributions... they would share a theory they had been given... we have this whole sense of interdisciplinary collaboration which I think is really good. (P5)

Whilst studying in ESL can be challenging for some students (Burns, 1991; Kingston and Forland, 2004), four participants had completed an English language qualification in the UK before university and felt relatively confident. Although participants did acknowledge the benefit of practicing ESL at PASS:

In PASS I didn't really speak to many at first... now I talk to everyone and never really stick to one person. You talk to people and that's how you improve your language, listening and speaking skills... you can practice your English for free. (P4)

However, some participants described language barriers within PASS: 
Language is very difficult for us... sometimes they were talking about something I didn't quite understand... if the leader doesn't try talking to international students they will just stay there not talking. (P2)

The reason why I didn't speak in the beginning... is because people don't understand me and then I have to repeat myself over and over. (P6)

\section{Shared study practice}

Participants described the value of revisiting course material, preparing for assignments and revising for exams in PASS:

We recapped on what we've been doing for each module... before the exams we were given practical help... with previous exam questions. (P1)

If we had set reading and then we could all discuss the reading and just someone else saying their interpretation of it would give you confidence that I did understand. (P5)

\section{Cultural practice}

Regarding the adjustments to multiple new cultural frameworks for some international students (Schmidt and Miller, 2009, p.13), participants described the culture shock on arrival at university:

Students come here and probably they didn't live here before so they feel strange, everything is strange here, everything is new. (P2)

Others described how PASS helped adjust to student life and UK HE:

Being new and international I felt that I could ask some questions. Small things like how could you find a job? Can you recommend how I use the library... if you hear it from... students in the PASS group that is much better for international to adjust in a new community. (P4) 
It had big effect on me when we started lectures because most times I'm thinking this is quite different... we spend up to seven hours of lectures a day in Nigeria. Here we just have ten hours of lecture per week and then you do the rest yourself... Afterwards we [PASS group] would meet at the library and talk about what we had done. (P6)

\section{Participation}

The theme 'participation' is defined as 'a process of taking part and also...the relations with others that reflect this process' (Wenger, 1998, p.53), focusing less on individual acquisition of knowledge and more on social participation for learning. The following further themes emerged:

\section{Motivating participation}

Participants described attending PASS motivating their independent study habits, and encouraging some to continue meeting with course peers to do PASS-like studying in their second year:

Friends I made in PASS helped me a lot because I'm just an average student... they work hard and knowing them motivates me to do something because I know they are out there at home doing something, and then maybe tomorrow we will discuss what we've done. (P6)

In my second year we have lots of mini PASS sessions in the library between lectures where we all discuss, so I think I subconsciously carried on doing it... it gave you the confidence to sit and ask. (P5)

\section{Barriers to participation}

P3 stopped participating in PASS after a couple of sessions due to awkward social dynamics and her misunderstanding of the role of leaders - expecting them to teach, she perceived the leaders to be unhelpful. However, after joining another group, realised she had missed out and became a PASS leader: 
She invited me to another group... I went to sessions and they were really good... I realised that I missed something that could have been good... it wasn't like you walk in, get your class and walk out, because I felt like that was what ours was like, and I thought I don't really need an extra lecture. (P3)

Other participants referred to barriers to their participation and suggested improvements:

I didn't really speak to many at first... in the beginning when we had to do ice breakers to get to know each other, that was a bit hard... I had to remember all their names... I couldn't pronounce them right. (P4)

For international students I think PASS is very leader dependent, my leaders were a bit disorganised... they would just rock up and say 'what do you want to do' without a backup plan... as an international student especially if English wasn't your first language you want a structure to follow... to feel a bit more secure. (P5)

\section{Discussion}

The overarching findings and arising questions emerging for each theme shall be discussed.

\section{Community}

Handley et al.'s (2006) problematisation of Wenger's (1998) notion of community is reinforced by this research: the PASS CoP is not a homogenous group, but rather heterogeneous, with blurred, intersecting boundaries. PASS provides international students with a CoP, facilitating peer relationships on their course and across year groups. PASS supports students' transition from their previous educational institution CoP, to joining the CoP on their course, discipline and university. The intersecting nature of the multiple CoP international students join on arrival at university raises questions about the differences between PASS and course CoP. The most distinguishing dimension seems to be the lack of the lecturer or discipline expert in PASS. The disadvantage of this is that PASS risks being unable to capture a full picture of the discipline, and the role of PASS leaders could be misunderstood to be inadequate, cost-free teaching. The advantage of the lecturer's absence is that PASS leaders can share their expertise and experience of 
student life and their degree at their institution. It also highlights the value of involving experienced students in providing new-student course inductions, which international students can particularly benefit from in their adjustments.

\section{Practice}

PASS supports international students in practicing a range of languages relating to studying in UK HE, including ESL, a shared language of learning in UK HE, and the language of the discipline. PASS provides opportunities for international students to better understand course material, make sense of cultural norms, and have an open space for dialogue with peers to practice their discourse (Bohm, 1996). This study highlights the importance of educational practitioners, including PASS leaders, taking an inclusive approach in the classroom, ensuring international students fully understand the reasons for pedagogical practices used in UK HE and the expectations upon them (Couchman, 2008).

A significant feature of learning in UK HE is students' involvement in the generation of new knowledge, which is prompted through an enquiry-based curriculum (Healey, 2005; Brew, 2003). A critique of CoP concept is that it focuses on how members acquire existing knowledge within a community, but doesn't address the question of how new knowledge is generated (Edwards, 2005). This questions whether students in PASS are learning existing, or creating new, knowledge. Amongst PASS leaders and participants there will be varying levels of understanding and knowledge. Through collaboration, students can gain clarification, consequently learning knowledge that is new to them, but which already exists amongst some members of the PASS CoP and more widely in the discipline/course CoP. Therefore PASS seems to serve as an intermediary CoP, supporting international students in understanding existing knowledge of their course, and transitioning into fuller participation in their course CoP, where opportunities for generating new knowledge are facilitated through the curriculum.

\section{Participation}

This research challenges Lave and Wenger's (1991) assumptions that legitimate peripheral participation is a positive experience enabling learners to adopt the culture of practice. Similar to O'Donnell and Tobbell's (2007) observations about the challenges for mature students' transition into HE, for some international students their legitimate 
peripheral participation is not necessarily a positive construction, but one of confinement, stress and isolation due to the challenges experienced (Sovic, 2008; Burns, 1991). This reinforces the benefit of PASS providing an inclusive and supportive environment, and the importance for PASS leaders to be equipped with cultural awareness, an understanding of the challenges experienced by international students, and facilitation techniques to address language barriers and social integration (Chilvers, 2013).

In light of the common problem of low participation in taught classes across HE (Moore et al., 2008; Massingham and Herrington, 2006), for students in this study PASS was beneficial in motivating their participation in peer learning and independent study. CoP concept identifies motivation as a by-product of participation in a CoP (Lave and Wenger, 1991), suggesting the potential for PASS to motivate, not just the motivated students (McGee, 2005), but also the less enthused and engaged students, particularly internationals who might be unfamiliar with peer learning or group work.

Edwards (2005) argues that defining 'participation' is a weakness of CoP concept as it only focuses on the social and collective dimensions of learning by participation, disregarding the cognitive and individual dimensions. This implies limitations to the use of the CoP concept in this research, suggesting other conceptual frameworks could illuminate other dimensions to the learning and transition experiences of international students in PASS. Additionally, whilst CoP identifies a number of different learning trajectories that a person can take in their participatory learning, it neglects to define the notion of 'full participation'. However, this research illuminates the difficulty of defining 'full participation' in the context of studying in HE, where participation might look differently for individual students depending on their circumstances or aspirations (Handley et al., 2006), and particularly for international students due to the challenges that often restrict their participation. Despite these limitations to CoP concept, its explanatory power for understanding interrelationships for learning, and the interconnected, multidimensional aspects of learning, has been very useful for this research.

\section{Conclusions}

Using CoP concept has been useful for building upon literature and further illuminating the role of PASS in supporting international students' transition and learning in HE. Findings 
highlight PASS providing international students with an intermediary CoP, supporting their boundary crossing and transition experiences for joining, and more fully participating in, a UK university. PASS can facilitate international students in adjusting to cultural norms and expectations; learning English, academic-specific, and discipline-specific languages and practices; encouraging social integration, and motivating participation; and independent study. International students receive a student-specialised induction to their course, student life and UK HE academic skills, stretching beyond induction week, throughout the potentially vulnerable first year.

Limitations to CoP concept have prompted questions about international students' experiences on the periphery of university learning communities, highlighting the importance of inclusive practice and support for international students. Questions remain concerning the investigation of international students' cognitive and individual participation for learning in UK HE.

This exploratory research should now be developed, with larger scale investigations to elicit richer data. Limitations to CoP identified in this study could be explored, as could other dimensions to CoP concept such as identity. For example, how does engaging in PASS as a CoP impact students', and specifically international students', constructions of their discipline identity? This could be helpful for informing the ongoing internationalisation of course curricula and development of learning support for international students.

\section{References}

Anderson, G., Carmichael, K.Y., Harper, T.J. and Huang, T. (2009) 'International students at four-year institutions: developmental needs, issues and strategies', in Harper, S.R. and Quaye, S.J. (eds.) Student engagement in higher education: theoretical perspectives and practical approaches for diverse populations. London, United Kingdom: Routledge, pp. 17-27.

Arendale, D. (1994) 'Understanding the Supplemental Instruction (SI) model', New Directions for Teaching and Learning, 60(4), pp. 11-22. 
Ashley, L.D. (2012) 'Case study research', in Arthur, J., Waring, M., Coe, R. and Hedges, L. (eds.) Research methods \& methodologies in education. London, United Kingdom: Sage, pp. 102-106.

Biggs, J. (2003) 'Teaching international students', in Biggs, J. (ed.) Teaching for quality learning at university. $2^{\text {nd }}$ edn. Maidenhead, United Kingdom: Open University Press, pp. 120-139.

Bohm, D. (1996) On dialogue. New York, NY: Routledge.

Brew, A. (2003) 'Teaching and research: new relationships and their implications for inquiry-based teaching and learning in higher education', Higher Education Research and Development, 22(1), pp. 3-18.

British Educational Research Association (BERA) (2011) Ethical guidelines for educational research. Available at: http://www.bera.ac.uk/publications/ethical-guidelines (Accessed: 6 May 2014).

Burns, R. (1991) 'Study and stress among first year overseas students in an Australian university', Higher Education Research and Development, 10(1), pp. 61-77.

Caruana, V. and Spurling, N. (2007) 'The internationalisation of UK higher education: a review of selected material [online]', London, United Kingdom: Higher Education Academy. Available at:

https://www.sussex.ac.uk/webteam/gateway/file.php?name=lit-reviewinternationalisation-of-uk-he-v2\&site=44 (Accessed 27 April 2016).

Chilvers, L. (2013) Factors influencing international students' participation in the Peer Assisted Study Sessions (PASS) programme: a small-scale study drawing on the Theory of Planned Behaviour. Unpublished master's thesis. University of Brighton, United Kingdom.

Coe, E., McDougall, A. and McKeown, N. (1999) 'Is peer assisted learning of benefit to undergraduate chemists?', University Chemistry Education, 3(2), pp. 72-75. 
Couchman, J. (2008) 'Who am I now? Accommodating new higher education diversity in Supplemental Instruction', Journal of Peer Learning, 1(1), pp. 80-89 [Online]. Available at: http://ro.uow.edu.au/ajpl/vol1/iss1/10 (Accessed: 16 May 2015). Creswell, J. (2009) Research design: qualitative, quantitative, and mixed methods approaches. $3^{\text {rd }}$ edn. London, United Kingdom: Sage.

De Vita, G. (2002) 'Cultural equivalence in the assessment of home and international business management students: a UK exploratory study', Studies in Higher Education, 27(2), pp. 221-231.

De Vita, G. and Case, P. (2003) 'Rethinking the internationalisation agenda in UK higher education', Journal of Further and Higher Education, 27(4), pp. 383-398.

Edwards, A. (2005) 'Let's get beyond community and practice: the many meanings of learning by participating', The Curriculum Journal, 16(1), pp. 49-65.

Forland, H. (2006) 'The international student learning experience: bridging the gap between rhetoric and reality', Going Global 2: The UK's International Education Conference. Edinburgh, Scotland 6-8 December.

Fostier, M. and Carey, W. (2007) 'Exploration, experience and evaluation; Peer Assisted Study Scheme (PASS): Sharing the experience of the University of Manchester: 4801 st year bioscience students', Science, Learning and Teaching Conference. Keele University, United Kingdom 19-20 June.

Gu, Q. (2005) 'Enjoying loneliness: understanding Chinese learners' voices', Humanising Language Teaching, 7(6) [Online]. Available at: http://www.hltmag.co.uk/nov05/index.htm (Accessed: 11 August 2015).

Guba, E. and Lincoln, Y. (1994) 'Competing paradigms in qualitative research', in Denzin, N. and Lincoln, Y. (eds.) Handbook of qualitative research, pp. 105-117. London, United Kingdom: Sage.

Haggis, T. (2006) 'Pedagogies for diversity: retaining critical challenge amidst fears of ‘dumbing down', Studies in Higher Education, 31(5), pp. 521-535. 
Handley, K., Sturdy, A., Fincham, R. and Clark, T. (2006) 'Within and beyond communities of practice: making sense of learning through participation, identity and practice', Journal of Management Studies, 43(3), pp. 641-653.

Healey, M. (2005) 'Linking research and teaching to benefit student learning', Journal of Geography in Higher Education, 29(2), pp. 183-201.

Holstein, J.A. and Gubrium, J.F. (2003) Inside interviewing: new lenses, new concerns. London, United Kingdom: Sage.

Jones, J. and Fleischer, S. (2012a) 'Should I stay or should I go? Factors affecting first year international students' decisions to leave or continue with degrees', Proceedings of the Annual Learning and Teaching Conference Post Conference Publication: Transitions: Quality, Adaptability and Sustainability in Times of Change. University of Brighton, United Kingdom 15 July 2011, pp. 31-41.

Jones, J. and Fleischer, S. (2012b) 'Staying on course: factors affecting first year international students' decisions to persist or withdraw from degrees in a post-1992 UK university', Practice and Evidence of Scholarship of Teaching and Learning in Higher Education, 7(1), pp. 21-46.

Kingston, E. and Forland, F. (2004) 'Bridging the gap in expectations between international students and academic staff', European Conference on Educational Research Post Graduate and New Researcher Pre-Conference. University of Crete, Crete 20-21 September. Available at: http://www.leeds.ac.uk/educol/documents/00003751.htm (Accessed: 17 June 2014).

Krause, K. (2005) 'Engaged, inert or otherwise occupied?: deconstructing the 21st century undergraduate student', Sharing Scholarship in Learning and Teaching: Engaging Students. James Cook University symposium. James Cook University, Australia 2122 September. Available at:

http://www.griffith.edu.au/ data/assets/pdf file/0005/53465/Engaged,inert2005.pdf (Accessed: 17 June 2014). 
Kvale, S. and Brinkman, A. (2009) InterViews: learning the craft of qualitative research interviewing. $2^{\text {nd }}$ edn. London, United Kingdom: Sage.

Lave, J. and Wenger, E. (1991) Situated learning: legitimate peripheral participation. Cambridge, United Kingdom: Cambridge University Press.

Lenning, O., and Ebbers, L. (1999). The Powerful Potential of Learning Communities: Improving Education for the Future. ASHE-ERIC Higher Education Report, 26 (6), ERIC Document Reproduction Service No. ED 428606.

List, S. and Miller, J. (2013) 'Students supporting students, using undergraduate communities of practice and Peer Assisted Study Sessions (PASS)', Higher Education Research Group Adelaide (Unpublished seminar abstract). University of Adelaide, Australia 5 September. Available at:

http://blogs.adelaide.edu.au/pedagogy/files/2013/09/sept5-seminar22.pdf (Accessed: 13 May 2014).

Mason, J. (2002) Qualitative researching. $2^{\text {nd }}$ edn. London, United Kingdom: Sage.

Massingham, P. and Herrington, T. (2006) 'Does attendance matter? An examination of student attitudes, participation, performance and attendance', Journal of University Teaching and Learning Practice, 3(2), pp. 82-103 [Online]. Available at: http://ro.uow.edu.au/jutlp/vol3/iss2/3 (Accessed: 1 December 2014).

Maundeni, T. (2001) 'The role of social networks in the adjustment of African students to British society: students' perceptions', Race, Ethnicity and Education, 4(3), pp. 253276.

McGee, J. (2005) Cognitive, demographic, and motivational factors as indicators of helpseeking in Supplemental Instruction. Unpublished doctoral dissertation. Texas A and M University, College Station, TX.

Merriam, S.B. and Caffarella, R.S. (1999) Learning in adulthood: a comprehensive guide. $2^{\text {nd }}$ edn. San Francisco, CA: Jossey-Bass. 
Montgomery, C. and McDowell, L. (2009). Social Networks and the international student experience: a community of practice to support learning? Journal of Studies in International Education, 13 (4), pp 455-466.

Moore, S., Armstrong, C. and Pearson, J. (2008) 'Lecture absenteeism among students in higher education: a valuable route to understanding student motivation', Journal of Higher Education Policy and Management, 30(1), pp.15-24.

O’Donnell, V.L. and Tobell, J. (2007) 'Peripheral participation in a community of practice? The transition of adult students to higher education: legitimate peripheral participation in a community of practice?', Adult Education Quarterly, 57(4), pp. 312328.

Parker, J. (2002) 'A new disciplinarity: communities of knowledge, learning and practice', Teaching in Higher Education, 7(4), pp. 373-386.

Schmidt, L. and Miller, J. (2009) 'Peer Assisted Study Sessions to facilitate transition for international students', The International Journal of Diversity in Organisations, Communities \& Nations, 9(5), pp. 13-29.

Sovic, S. (2008) Lost in transition? The international students' experience project. Centre for Excellence in Teaching and Learning: Creative Learning in Practice: project report. London, United Kingdom: University of the Arts London. Available at: https://www.sussex.ac.uk/webteam/gateway/file.php?name=art-and-designinternational-students-experience-project\&site=44 (Accessed: 4 June 2014).

Thomas, L. (2012) Building student engagement and belonging in higher education at a time of change: Final report from the What works? Student retention \& success programme: research report. London: Paul Hamlyn Foundation. Available at: https://www.heacademy.ac.uk/sites/default/files/what works summary report 1.pdf (Accessed: 13 May 2014).

Tinto, V., Russo, P. and Kadel, S. (1994) 'Constructing educational communities: increasing retention in challenging circumstances', Community College Journal, 64(4), pp. 26-29. 
Tobbell, J. and O'Donnell, V. (2005) 'Theorising educational transitions: communities, practice and participation', Conference on Sociocultural Theory in Educational Research and Practice. University of Manchester, United Kingdom 8-9 September [Online]. Available at: http://eprints.hud.ac.uk/7743/ (Accessed: 6 June 2014).

Vygotsky, L.S. (1978) Mind in society: the development of higher psychological processes. London, United Kingdom: Harvard University Press.

Wenger, E. (1998) Communities of practice: learning, meaning and identity. Cambridge, United Kingdom: Cambridge University Press.

Wheeldon, J. and Faubert, J. (2009) 'Framing experience: concept maps, mind maps, and data collection in qualitative research', International Journal of Qualitative Methods, 8(3), pp. 1-16 [Online]. Available at: http://wiganojs.library.ualberta.ca/index.php/IJQM/article/view/1765/5591 (Accessed: 6 October 2015).

Yorke, M. and Longden, B. (2008) The first-year experience of higher education in the UK - Final Report. York, United Kingdom: Higher Education Academy.

Zaccagnini, M. and Verenikina, I. (2013) 'Peer Assisted Study Sessions for postgraduate international students in Australia', Journal of Peer Learning, 6(1), pp. 86-102. Available at: http://ro.uow.edu.au/cgi/viewcontent.cgi?article=1052\&context=ajpl (Accessed: 13 August 2015).

Zhao, C. and Kuh, G.D. (2004) 'Adding value: learning communities and student engagement', Research in Higher Education, 45(2), pp. 115-138.

\section{Author details}

Lucy Chilvers is a Senior Lecturer in Learning Development based in the Centre for Learning and Teaching at the University of Brighton. Through her role she is interested in enhancing students' transition, academic engagement, progression and personal and professional development throughout higher education. Lucy coordinates and co-develops 
resources and initiatives, including the PASS Programme, that support students in their learning. She conducts research into aspects of these various initiatives, seeking to further develop practice and understanding of how best to support and engage students in their learning and development. She also works with academic staff through consultation and teaching to enhance their own pedagogic practices. 